\title{
The Effect of Training and Development on the Performance of Senior Administrative Staff at the University of Education, Winneba, Ghana
}

\author{
Moses Segbenya $^{1} \&$ Titus Berisie ${ }^{2}$ \\ ${ }^{1}$ Department of Business Studies, College of Distance Education, University of Cape Coast, Ghana \\ ${ }^{2}$ University of Education, Winneba, Central Region, Ghana \\ Correspondence: Moses Segbenya, Department of Business Studies, College of Distance Education, University \\ of Cape Coast, Ghana. E-mail: moses.segbenya@ucc.edu.gh
}

Received: November 22, 2019

Accepted: December 10, 2019

Online Published: January 13, 2020

doi:10.5539/ijbm.v15n2p49

URL: https://doi.org/10.5539/ijbm.v15n2p49

\begin{abstract}
The study examined the effect of training and development on senior administrative staff's performance at the University of Education, Winneba, Ghana. Quantitative approach and the descriptive survey research design were adopted for the study. Simple random sampling technique was used to sample 152 respondents from a population of 357 using Yamane's formula for determining sample size. Self- administered closed ended questionnaire was used as the data collection instrument and data was analysed with frequencies, percentages, person correlation, standard regression, t-test and analysis of variance. The study found that training and development techniques used were job rotation and study leave with pay. There was general lack of support from supervisors and colleagues for trainees to transfer skills/knowledge acquired unto their jobs. Training and development significantly relate and affect employees' performance. It was recommended that management of human resource department of the University of Education, Winneba should adopt some other training and development techniques like mentoring and coaching; and provide the needed resources and encourage work colleagues and supervisors to create the enabling environment and provide the necessary support for trainees to be able to transfer skills acquired through training and development unto their jobs.
\end{abstract}

Keywords: training and development, employees performance

\section{Introduction}

The human resource of every organisation debatably continues to remain as the most important resource without which all other resources remain inactive (Segbenya, Peniena \& Aggrey, 2018). The attainment of organisational goals and the ability to maintain organisational position or pinnacle in the market largely depend on the skills and competencies of its employees (Mullins,2010). Thus, customers' satisfaction in terms of quality services and products delivery can be said to be contingent upon employees of every organisation. Additionally, the human resource enables every organisation to make returns on investment made by investors. The human resource theory thus argues that the human resource of every organisation constitutes the rare and inimitable asset to every organisation. Thus, whiles it is easy over time for an organisation to imitate a product of its competitors, the same cannot be said in terms of imitating the skills and competencies of the human resource of competitors.

According to Sefenu and Nyan (2017) employees normally enter an organisation with some sort of skills or competencies. However, the dictates of task to be performed by employee and or the overall direction of the organisation most at times renders such skills and competencies inadequate. Even more, the dynamism in the business environment and advancement in technology equally renders the current skills and competence of employees useless towards individual workers and the organisation's performance. It is against these backdrops that training and development of employees of every organisation cannot be relegated to the background in the $21^{\text {st }}$ century and beyond if organisations want to remain competitive.

Training and development seek to formally and consistently modify the behaviour of workers through learning as a result of planned experience, education and instructions. Training and development have two main purposes such as to add value in terms of skills and competencies of a worker and secondly, to enhance both workers and management's performance. Training and development when properly conducted serve as source of motivation 
to the employees in the organisation. Most organisations as part of their long-term planning make provision for employees training and development to optimize their potential and build new skills in the workforce (Boadu, Dwomo-Fokuo, Boakye \& Kwaning, 2014). This new skills and knowledge enable these workers to cope with the uncertain conditions that they may face in future thus improving the employee performance through superior level of motivation and commitment (Elnaga \& Imran, 2013). Additionally, Sultana, Irum, Ahmed, and Mehmood (2012) and Sefenu (2017) posit that training and development minimizes production costs in general, improves individual and team's performance in terms of output, quality, speed and overall productivity. In the view of Gamage and Imbulana (2013) and Jehanzeb and Bashir (2013), highly skilled, motivated and boosted morale workforce will be created if the organisations conduct training and development programmes and follow the due processes.

Training also minimizes the difference between current performance of employees and the expected performance (Elnaga \& Imran, 2013). Managers are now investing in training and development programmes because they have now recognised the important role it plays in reducing the difference between current skills and the skills required to cope with changing technology (Mansour, 2013). Thus, training and development does not only prepare the workforce for their current jobs but also prepares them for future job opportunities by focusing on both supervisory and non-supervisory category of workers. Noe (2010) and Werner and DeSimone (2012) argued that for training and development to drive home the needed benefit to any organisation and its workforce, trainers must pay attention to training and development processes. These processes included need assessment, instructional design, validation of design, design implementation and evaluation and follow-up (Dessler, 2008). According to Ongori and Nzonzo (2011) and Sefenu and Nyan (2017), training for workers could be either on-the-job or Off-the-Job forms of training and development.

Training and development is equally relevant to sustain the performance of universities in Ghana and that the University of Education, Winneba is not an exception. This is because, the university performance and ability to satisfy its stakeholders over the years and in the future largely depends on her workforce. The university has both supervisory and non-supervisory workforce who can be found in both teaching and non-teaching departments in the university meeting the needs of teaming students' population among others.

University of Education, Winneba (UEW) which was formerly known as University College of Education of Winneba (UCEW) is a public tertiary educational institution comprising of four (4) campuses. Two of the campuses are in the Central Region of Ghana and the remaining two are in the Ashanti Region. The University of Education, Winneba like any tertiary institution operating in this global dynamic environment is concerned about efficient and effective delivery of its services to stakeholders as well as to remain competitive in the tertiary education sector. This calls for continuous training and development to enhance the skills and competencies of the university's workforce especially the senior administrative staff (SAA). The senior administrative staff (the focus of this study) works closely with the various Heads of Department in the university to assist in the implementation of the University's policy to achieve its objectives. Training and development for Senior administrative assistant of the university means better equipped personnel to offer better assistant to their Heads of Department to deliver their mandates. Continuous training for this category of staff also makes them "trainers of trainees" for their subordinates whose activities are supervised by these SAA.

There are still records of performance challenges despite all the attempts made by the University of Education, Winneba (UEW) to improve the competencies of its employees to meet their performance target. A check from performance appraisal records of some of the employees for 2014 and 2016 showed same margin of error and the average score of performance rating had still not changed much over the period. Performance appraisal of employees always serves as one of the sources of arriving at the decision to train and develop organisation workforce. Thus, the need to find out whether the underperformance, of employees over the years has a link with the kind of training or lack of training given to these senior administrative staff of the university. This gap necessitated this study. It is for this reason that this study sought to examine the effect of training and development on the performance of senior administrative staff of the University of Education, Winneba. This, therefore, necessitated the formulation of two research questions and three hypotheses such as:

1. How are training and development programmes carried out for Senior Administrative Staff of UEW?

2. How does training and development affect the performance of Senior Administrative Staff in UEW?

The study was also guided by hypotheses such as:

Hypothesis one

$\mathrm{H}_{1}$ : There is statistically positive and significant relationship between employee's performance and 
constructs of training and development.

Hypothesis two

$\mathrm{H}_{1}$ : There is statistically significant difference between sex and factors of the study such as $\mathrm{T}$ \& $\mathrm{D}$ needs assessment, T \& D Techniques and perception of T \& D and employee performance.

Hypothesis three

$\mathrm{H}_{1}$ : There is statistically significant difference between tenure or years of working experience and factors of the study such as T \& D needs assessment, T \& D Techniques and perception of T \& D and employee performance.

\subsection{Theoretical and Conceptual Discussion on Training and Development}

This study is based on human capital theory proposed by Schultz in 1961 and developed by Becker in1994 (Becker, 1996). Ongori and Nzonzo (2011) define human capital as "knowledge, skills, and capabilities of individuals that have economic value to an organisation. Human capital theory suggests that education or training raises the productivity of workers by imparting useful knowledge and skills unto employees, which can also lead to the raising of workers' future income by increasing their lifetime earnings (Gunu, Oni, Tsado, \& Ajayi, 2013). The human capital theory suggests that an individual's or organisation's decision to invest in training is based on an examination or expectation of the net present value of the costs and benefits of such an investment. Becker distinguishes between specific human capital and general human capital. Specific human capital includes expertise acquired through education and training which is specific to a firm (firm-specific or context-specific skills). General human capital (general skills), on the other hand, is knowledge gained through education and training which is valuable across board.

Individuals or organisations are assumed to invest in training because of expected returns of the investment that they would receive in subsequent later dates. Thus, human capital is a means of production into which additional investment yields additional output. Human capital is substitutable, but not transferable like land, labour, or fixed capital. Meanwhile, several authors have criticized the human capital theory by pointing out that economists and other social scientists have overestimated the payoffs from increased education and ignored complimentary inputs such as, training, contract terms, and management practices which must exist for education to improve productivity (Alyahya, Norsiah, \& Alharbi, 2013). That notwithstanding this study agrees with Fugar, Ashiboe-Mensah, \& Adinyira, (2013) that Becker's human capital theory remains resilient principal theoretical construct that is used for understanding human capital investment from both the firm and the individual perspectives.

\subsection{Training and Development}

Training can be referred to as the formal and systematic process of modifying the behaviour of employees through learning which can occur as a result of planned experience, instruction and education (Werner \& De-Simone, 2012). Employee Development on the other hand could be described as the process of improving managers' performance in their present roles whiles preparing them for job responsibilities in the future (Dessler, 2008; Naris \& Ukpere, 2009; Khan, Khan \& Mahmood, 2012). Sefenu and Nyan (2017) differentiated between training from development by indicating that training relates to more focused on shorter period, specific tasks and less supervisory workers. Employee development or management development on the other hand focuses on supervisory workers, last longer and prepares workers for future responsibilities. Noe (2010) is of the opinion that though training is important, it can only be effective when it has a linked with performance problem and is geared toward the achievement of the organisation's objectives. However, it can be said that the benefits of training and development can only be derived if organisation and trainers take into consideration how training and development is organised for employees. An effective training and development programmes have been suggested in literature to have five main considerations (Werner \& DeSimone, 2012; Kum and Cowden, 2014; Amadi, 2014).

The first of these considerations is called needs assessment which focuses on employee who need to be trained and what kind of training would be required (Noe, 2010). Werner and DeSimone (2012) described needs analysis as determining training gaps between what an employee can do now and what he would expect to do in the future. The training gap could be identified through performance appraisal among others and or examination of employees' present skills and what is required for carrying out his/her schedules/task can lead to training gap identification. Another method for identifying the training gap is to compare the employees' present skills with what skills would be needed for attainment of the organisational goals.

The second consideration that every effective T \& D programmes should consider after the need assessment is instructional design. Instructional design refers to the systematic and reflective process of translating principles 
of learning and instruction into plans for instructional materials, activities, information resources, and evaluation (Alyahya, Norsiah, \& Alharbi, 2013). At the instruction design stage, attention is given to gathering instructional objectives, methods, media, and complementary sequence of content (Noe, 2010). Validation of design is the third consideration where the training programme is tested or clean-up by presenting to a small representative audience (Sefenu \& Nyan, 2017). Design implementation, the fourth consideration focuses on carrying out the developed instructional or training programme. Lastly, evaluation and follow-up consider assessment of the training programmes' success or otherwise. According to Werner and DeSimone (2012) some other forms by which training evaluation could be done included, immediate trainees' reactions to training, pre and post test, the degree to which a trainer apply the new skills or knowledge to their jobs. Training and development techniques can be broadly grouped into on-the-job and off-the-job techniques.On-the-job training techniques include apprenticeship, coaching, job rotations, action learning, case study, management game and special assignment. Off-the-job training and development techniques also include audiovisual, lecturing/seminars/tutoring, vestibule and simulated training among others.

Irrespective of type of training and development technique/s adopted by any organisation, the overall goal of enhancing employee and organisational performance should not be compromised. A properly conducted training and development programme is a source of motivation to the employees in the organisation (Coffie1, Boateng \& Coffie, 2018). Most organisations as part of their long-term planning make provision for employees training and development to optimize their potential and build new skills in the workforce to enable them to adapt and overcome uncertain conditions that they may face in the future which will translate into improvement of the employee performance (Elnaga \& Imran, 2013). Mullins (2010) indicated that training affect behaviour of employees and their working skills, which resulted in enhanced employee performance and further constructive changes that leads to increase employee performance.

\subsection{Conceptual Framework of the Study}

The conceptual framework of the study argues that training and development sections or activities in an organisation could either be termed as effective or ineffective. Steps of activities that leads to effective training and development in organisation or otherwise have been indicated. Effective training and development of staff must lead to skills/knowledge enhancement for trainees. The extent to which enhanced skills/knowledge acquired from $\mathrm{T} \& \mathrm{D}$ programmes by trainees are transferred unto their jobs or schedules highly depends on the management/supervisor supports and availability of resources. The conceptual framework of the study further argues that trainees' transferability of skills unto their jobs leads to enhanced employee performance. However, the extent to which performance is enhanced could be influenced by demographic characteristics such as educational levels, age and tenure or working experience. Figure 1 thus illustrate these issues in the conceptual framework.

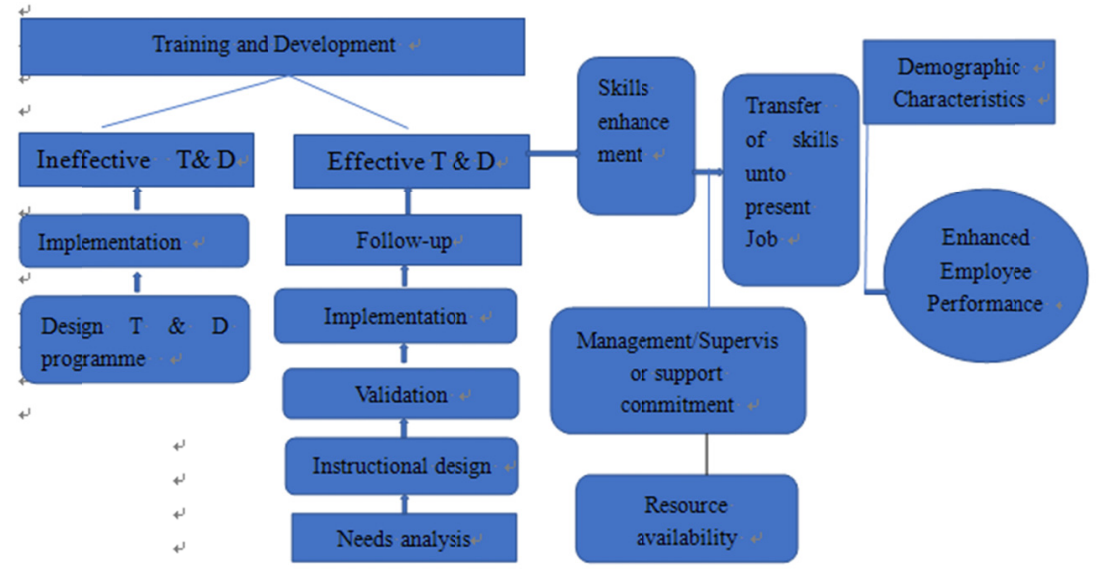

Figure 1. Conceptual framework of the study showing how $\mathrm{T}$ and $\mathrm{D}$ process can enhance the skills and competences of employees leading to high/enhanced employee performance

Source: Authors' Own Construct (2018).

\section{Methodology}


This study adopts the positivist epistemic paradigm and the quantitative approach and specifically, the survey research design. Creswell (2014) explained a quantitative research approach as the study which explains phenomena by collecting numerical data that are analysed using mathematically based statistical methods. For this study, the population was 357 Senior Administrative Staff in University of Education, Winneba, Winneba Campus comprising 224 males and 133 females. The sample size for a study was determined with Yamane's formula to arrive at the appropriate number of staff or sample for the study. The Yamane's Formula for Determining Sample Size used was:

$$
n=N / 1+N(e) 2
$$

Where: $\mathrm{n}=$ sample size, $\mathrm{N}=$ population, $1=$ constant, $\mathrm{e}=$ margin of error (level of significance). Hence with confidence interval of $95 \%$, with total population of 357 , the sample size was 189 . The simple random sampling technique was used in this study. It is a technique of sampling that give equal opportunity to every variable in the population of being part of the sample. A self-administered questionnaire constitutes the data collection instruments. A questionnaire was adopted because the participants were literate and could read and respond to the items on their own. A pre-test was conducted to determine the reliability and the validity of the instrument. The pilot study was conducted in the Perez University College at Pomadze near Winneba with twenty (20) respondents. Cronbach's alpha was used to check the reliability and internal consistency of items on the questionnaire. The instrument yielded a high reliability of 0.89 . The main data collection was carried out in June 2017. Out of one hundred and eighty-nine (189) questionnaire sent out the study recorded $80.9 \%$ respond rate (152).

Both descriptive and inferential statistics were used to analyse the quantitative data collected. Specifically, descriptive statistics such as percentages and frequencies were used to analyse research objective one. Standard multiple regression was used to analyse objective two Inferential statistics such as Pearson correlation and standard multiple regressions were used to respectively determine relationship and the effect of training and development on senior administrative staff performance at UEW. The hypotheses of the study were analysed using student t-test and One-Way Analysis of Variance (ANOVA).

\section{Result and Discussion}

Presentation of results and discussion is based on the research questions and hypotheses guiding the study. Results for the two research questions are presented and discussed before same is done for the hypotheses. The results for the first research question which sought to examine the perception of how training and development programmes were carried out for Senior Administrative Staff of UEW, can be seen in Table 1. The result in Table 1 reveals that the majority (41.4\%) of respondents concluded that the present system of training and development in the university was not very useful. That notwithstanding, 38.8\%; $43.8 \%$ and $65.4 \%$ (majority) of the respondents respectively agreed that training was necessary for developing employees'skills; training programmes were helpful in the long run, and were aware of training and development policy in the UEW. Majority of the respondents were also not very sure of acquisition of innovative ideas during training $(51.7 \%)$; training enhances the institution's effectiveness (39.2\%); employees had the interest of attending training programme (67.1\%), and UEW links training and development with its Strategic Plan (64.5\%).

The result means $\mathrm{T} \& \mathrm{D}$ was basically organised for this category of staff as a formality despite the knowledge on the importance of $\mathrm{T} \& \mathrm{D}$. This has the propensity of making it very difficult if not impossible to recoup investment in $\mathrm{T} \& \mathrm{D}$ programmes as well as achieve the benefits of $\mathrm{T} \& \mathrm{D}$ as concluded by Werner and DeSimone (2012). The authors found that T \& D carried out as a formality has little impact on performance and makes $\mathrm{T} \& \mathrm{D}$ as a cost element without any return. 
Table 1. Employees' general perception of training and development in EUW

\begin{tabular}{|c|c|c|c|c|c|c|c|}
\hline \multicolumn{2}{|l|}{ Perception about the training environment } & \multirow{2}{*}{$\begin{array}{l}\text { SD } \\
1\end{array}$} & \multirow{2}{*}{$\begin{array}{l}\mathrm{D} \\
4\end{array}$} & \multirow{2}{*}{$\begin{array}{l}\text { SWA } \\
11\end{array}$} & \multirow{2}{*}{$\begin{array}{l}\text { A } \\
100\end{array}$} & \multirow{2}{*}{$\frac{\text { SA }}{37}$} & \multirow{2}{*}{$\begin{array}{l}\text { Total } \\
153\end{array}$} \\
\hline Awareness of training and development policy & No & & & & & & \\
\hline UEW & $\%$ & 0.7 & 2.6 & 7.2 & 65.4 & 24.2 & 100 \\
\hline UEW links training and development with its & No & 2 & 13 & 99 & 30 & 9.0 & 153 \\
\hline Strategic Plan & $\%$ & 1.3 & 8.5 & 64.5 & 19.6 & 5.9 & 100 \\
\hline \multirow[t]{2}{*}{ Available training and development department } & No & 15 & 93 & 17 & 19 & 8 & 152 \\
\hline & $\%$ & 9.8 & 61.2 & 11.2 & 12.5 & 5.3 & 100 \\
\hline \multirow[t]{2}{*}{ Present training system is very useful } & No & 3 & 63 & 51 & 25 & 10 & 152 \\
\hline & $\%$ & 2.0 & 41.4 & 33.6 & 16.4 & 6.6 & 100 \\
\hline \multirow{2}{*}{$\begin{array}{l}\text { Employees have the interest in attending a training } \\
\text { programme }\end{array}$} & No & 5 & 10 & 102 & 22 & 13 & 152 \\
\hline & $\%$ & 3.3 & 6.6 & 67.1 & 14.4 & 8.6 & 100 \\
\hline \multirow[t]{2}{*}{ Training programmes are helpful in the long run } & No & 1 & 2 & 44 & 67 & 39 & 153 \\
\hline & $\%$ & 0.7 & 1.3 & 28.8 & 43.8 & 25.5 & 100 \\
\hline \multirow{2}{*}{$\begin{array}{l}\text { Training is necessary for any employee for } \\
\text { developing their skills }\end{array}$} & No & 0 & 2 & 57 & 59 & 34 & 152 \\
\hline & $\%$ & 0 & 1.3 & 37.5 & 38.8 & 22.4 & 100 \\
\hline \multirow[t]{2}{*}{ Training enhances organisation effectiveness } & No & 0 & 2 & 60 & 58 & 32 & 152 \\
\hline & $\%$ & 0 & 1.3 & 39.2 & 37.9 & 20.9 & 100 \\
\hline \multirow[t]{2}{*}{ Innovative ideas are acquired during training } & No & 2 & 15 & 78 & 33 & 23 & 151 \\
\hline & $\%$ & 1.3 & 9.9 & 51.7 & 21.9 & 15.2 & 100 \\
\hline
\end{tabular}

Source: Field survey (20017) $\mathrm{SD}=$ Strongly Disagree, $\mathrm{D}=$ Disagree, $\mathrm{SWA}=$ Somewhat Agree, $\mathrm{A}=$ Agree and $\mathrm{SA}=$ Strongly Agree.

The second aspect of the first research question looks at the extent to which training and development processes as depicted in the conceptual framework were followed by UEW in carrying out training and development programmes for the senior administrative staff of the university. From the conceptual framework determinacy of employees needs as the first step for $\mathrm{T}$ and $\mathrm{D}$ is a panacea for effective training and development. For this reason, the first part of this second section looks at the extent to which employees' training needs were sought by organisers of $\mathrm{T}$ and $\mathrm{D}$ programmes. Table 2 presents the results for the training needs assessment.

Table 2. Determining the training needs of senior administrative staff of UEW

\begin{tabular}{|c|c|c|c|c|c|c|c|}
\hline Training and development needs analysis & & SD & $\mathrm{D}$ & SWA & A & SA & Total \\
\hline \multirow{2}{*}{$\begin{array}{l}\text { The University staff training is organised based on the } \\
\text { identification of needs assessment. }\end{array}$} & No & 2 & 21 & 95 & 28 & 7 & 153 \\
\hline & $\%$ & 1.3 & 13.7 & 62.1 & 18.3 & 4.6 & 100 \\
\hline \multirow{2}{*}{$\begin{array}{l}\text { The Supervisor involves the employee in deciding the } \\
\text { training programme }\end{array}$} & No & 11 & 103 & 26 & 10 & 2 & 152 \\
\hline & $\%$ & 7.2 & 67.8 & 17.1 & 6.6 & 1.3 & 100 \\
\hline \multirow{2}{*}{$\begin{array}{l}\text { The University organises performance appraisal to } \\
\text { determine what employee lack. }\end{array}$} & No & 1 & 7 & 102 & 36 & 6 & 152 \\
\hline & $\%$ & 0.7 & 4.6 & 67.1 & 23.7 & 3.9 & 100 \\
\hline \multirow{4}{*}{$\begin{array}{l}\text { The mode of selection for training and development } \\
\text { programmes in the University is fair. } \\
\text { To a large extent employee training and development, } \\
\text { needs are met }\end{array}$} & No & 9 & 101 & 19 & 18 & 4 & 151 \\
\hline & $\%$ & 6.0 & 66.9 & 12.6 & 11.9 & 2.6 & 100 \\
\hline & No & 3 & 32 & 98 & 17 & 2 & 152 \\
\hline & $\%$ & 2.0 & 21.0 & 64.5 & 11.2 & 1.3 & 100 \\
\hline
\end{tabular}

Source: Field survey (20017). $\mathrm{SD}=$ Strongly Disagree, $\mathrm{D}=$ =Disagree, $\mathrm{SWA}=$ Somewhat Agree, $\mathrm{A}=$ Agree and $\mathrm{SA}=\mathrm{Strongly}$ Agree.

It can be seen from Table 2 that, $67.8 \%$ and $66.9 \%$ of respondents in the majority respectively concluded that the supervisor does not involve employees in deciding the training programme, and the mode of selection of trainees for training and development programmes in the University (UEW) was not fair. Majority of respondents also somewhat agreed that training was organised based on the identification of needs assessment $(62.1 \%)$; the University organises performance appraisal to determine what employee lack (67.1\%) and lastly, training and 
development needs were met (64.5\%). This suggests that the respondents were not very sure of these three later items. The failure to use appraisal and needs assessment to determine who and what type of training to be given to senior administrative staff of the University firstly confirms the earlier finding on formality of T \& D for this category of staff in the university. Secondly, the findings agree with that of Noe (2010) that T \& D programmes without recourse to need analyses leads to wrong $\mathrm{T} \& \mathrm{D}$ programmes for the right employees as captured in the conceptual framework of the study. Another issue captured in the conceptual framework which was of concern to this study was the kind of strategies or techniques adopted by the UEW to train and develop its senior administrative staff. The results of this effect can be seen in Table 3 .

Table 3. Training and development strategies/techniques

\begin{tabular}{|c|c|c|c|c|c|c|c|c|}
\hline & Items & & SD & $\mathrm{D}$ & SWA & A & SA & Total \\
\hline \multirow[t]{2}{*}{1} & Mentoring & No & 39 & 78 & 15 & 16 & 4 & 152 \\
\hline & & $\%$ & 25.7 & 51.3 & 9.9 & 10.5 & 2.6 & 100 \\
\hline \multirow[t]{2}{*}{2} & Coaching & No & 34 & 65 & 30 & 19 & 4 & 152 \\
\hline & & $\%$ & 22.4 & 42.8 & 197 & 12.5 & 2.6 & 100 \\
\hline \multirow[t]{2}{*}{3} & Induction training & No & 29 & 80 & 20 & 19 & 3 & 151 \\
\hline & & $\%$ & 19.2 & 53.0 & 13.2 & 12.6 & 2.0 & 100 \\
\hline \multirow[t]{2}{*}{4} & Professional Course & No & 34 & 96 & 14 & 8 & 1 & 152 \\
\hline & & $\%$ & 21.7 & 63.1 & 9.2 & 5.3 & 0.7 & 100 \\
\hline \multirow[t]{2}{*}{5} & Role Playing & No & 14 & 37 & 76 & 22 & 2 & 151 \\
\hline & & $\%$ & 9.3 & 24.5 & 50.3 & 14.6 & 1.3 & 100 \\
\hline \multirow[t]{2}{*}{6} & Study leave with pay & No & 2 & 3 & 53 & 64 & 30 & 152 \\
\hline & & $\%$ & 1.3 & 2.0 & 34.9 & 42.1 & 19.7 & 100 \\
\hline \multirow[t]{2}{*}{7} & Job rotation & No & 1 & 4 & 55 & 83 & 9 & 152 \\
\hline & & $\%$ & 0.7 & 2.6 & 36.2 & 54.6 & 5.9 & 100 \\
\hline
\end{tabular}

Source: Field survey, (2017).

$\mathrm{SD}=$ Strongly Disagree, $\mathrm{D}=$ Disagree, $\mathrm{SWA}=$ Somewhat Agree, $\mathrm{A}=$ Agree and $\mathrm{SA}=$ Strongly Agree.

Results from Table 3 shows the extent to which seven training and development techniques were rated by respondents to have been used by trainers for senior administrative assistants in the University of Education, Winneba. Majority of the respondents disagreed that four training and development techniques were used to train senior administrative assistants. These techniques were the use of professional course to train staff $(63.1 \%)$, induction training $(53.0 \%)$, coaching technique $(42.8 \%)$ and mentoring technique $(51.3 \%)$. The only two techniques indicated by the majority of the respondents to have been used for training senior administrative assistants in the University of Education, Winneba was job rotation (54.6\%) and study leave with pay (42.1\%). This means that the university uses limited on-the-job and off-the-job training methods in training administrative staff of the university which also limit the impact of T \& D on employees' performance as found by Sefenu and Nyan (2017). Sefenu and Nyan were of the view that different methods/techniques are needed for different category of workers depending on the type of needs for the T\& D.

The study went further to look at respondents' assessment of the availability of resources and support from immediate supervisors for transferring (implementation) of new knowledge acquired through training and development programmes unto their jobs. The results in Table 4 reveals that respondents do not receive support from work colleagues (38.4\%) and employees who use the knowledge acquired from training on their job do not get any preference for new opportunities $(65.1 \%)$. This means that the working environment does not encourage trainees to transfer knowledge acquired through training and development unto the jobs. This explains why the majority of the respondents could only somewhat agreed that resources were available to transfer knowledge unto their jobs (67.9\%) and the presence of similarity of equipment used on the job as compared to equipment used for training $(71.7 \%)$. The results mean that there was a general lack of organisational support for trainees to transfer knowledge acquired through training unto their jobs. This has the tendency to firstly demotivate workers to participate in future training programmes and secondly affect employees' performance negatively as conjectured by Sefenu and Nyan (2017).

Table 4 also shows the results on the extent to which trainees get support from their supervisors' to successfully transfer knowledge gained through training unto their jobs. Majority of the respondents disagreed that there was opportunity to apply the knowledge gained from training immediately $(57.2 \%)$, supervisors ease the 
workload to allow practising new skills after training $(63.6 \%)$ and supervisors assigned a mentor to trainees after training (55.6\%). This means that trainees hardly receive support from supervisors to transfer skills unto their jobs. This was further corroborated with respondents' assertions that supervisors' hardly support transferring techniques learned unto their jobs (67.3\%) and supervisors hardly help employees set realistic goals after training $(70.9 \%)$. Thus, it is obvious from the results in Table 4 that senior administrative assistants in the university hardly get support from colleagues and supervisors to transfer knowledge or skills learnt unto their jobs. This suggests that training programmes for this category of staff were carried out as a formality and not necessary to improve performance. It also suggests that cost incurred on training and development for senior administrative staff of the University would not be recouped since it might not lead to improve employees and organisational performance.

Table 4. Employee's perception of the availability of resources for transferring knowledge acquired from training and development unto their jobs

\begin{tabular}{|c|c|c|c|c|c|c|c|}
\hline Availability of resources & & SD & $\mathrm{D}$ & SWA & $\mathrm{A}$ & SA & TOTAL \\
\hline \multirow{2}{*}{$\begin{array}{l}\text { Availability of resources to support the implementation of what } \\
\text { employees learned from training }\end{array}$} & No & 4 & 14 & 106 & 25 & 3 & 152 \\
\hline & $\%$ & 2.6 & 9.2 & 69.7 & 16.5 & 2.0 & 100 \\
\hline \multirow[t]{2}{*}{ equipment used in training is like the equipment found on the job } & No & 7 & 13 & 109 & 18 & 5 & 152 \\
\hline & $\%$ & 4.6 & 8.6 & 71.7 & 11.8 & 3.3 & 100 \\
\hline \multirow{2}{*}{$\begin{array}{l}\text { Colleagues support the use of learning on the job after training } \\
\text { programmes }\end{array}$} & No & 4 & 58 & 49 & 35 & 5 & 151 \\
\hline & $\%$ & 2.6 & 38.4 & 32.5 & 23.2 & 3.3 & 100 \\
\hline \multirow{2}{*}{$\begin{array}{l}\text { Employees who use knowledge from training are given preference } \\
\text { for new assignments }\end{array}$} & No & 12 & 99 & 22 & 13 & 6 & 152 \\
\hline & $\%$ & 7.9 & 65.1 & 14.5 & 8.6 & 3.9 & 100 \\
\hline \multicolumn{8}{|l|}{ Supervisors support for the transfer of knowledge } \\
\hline \multirow[t]{2}{*}{ Feedback from supervisors on the impact of training } & No & 3 & 21 & 98 & 29 & 1 & 152 \\
\hline & $\%$ & 2.0 & 13.8 & 64.5 & 19.0 & 0.7 & 100 \\
\hline \multirow[t]{2}{*}{ Supervisors' support for transferring techniques learned to the job } & No & 6 & 15 & 103 & 26 & 3 & 153 \\
\hline & $\%$ & 3.9 & 9.8 & 67.3 & 17.0 & 2.0 & 100 \\
\hline \multirow[t]{2}{*}{ Supervisors help employees set realistic goals after training } & No & 7 & 16 & 107 & 16 & 5 & 151 \\
\hline & $\%$ & 4.6 & 10.6 & 70.9 & 10.6 & 3.3 & 100 \\
\hline \multirow[t]{2}{*}{ Supervisors assign an experienced employee to help after training } & No & 21 & 84 & 30 & 15 & 1 & 151 \\
\hline & $\%$ & 13.9 & 55.6 & 19.9 & 9.9 & 0.7 & 100 \\
\hline \multirow{2}{*}{$\begin{array}{l}\text { Supervisors ease the workload to allow practising new skills after } \\
\text { training }\end{array}$} & No & 15 & 96 & 25 & 10 & 5 & 151 \\
\hline & $\%$ & 9.9 & 63.6 & 16.6 & 6.6 & 3.3 & 100 \\
\hline \multirow{2}{*}{$\begin{array}{l}\text { Provision of opportunity to apply the knowledge gained from } \\
\text { training immediately }\end{array}$} & No & 10 & 87 & 34 & 18 & 3 & 152 \\
\hline & $\%$ & 6.6 & 57.2 & 22.4 & 11.8 & 2.0 & 100 \\
\hline
\end{tabular}

Source: Field survey (2017); SD=Strongly Disagree, D=Disagree, SWA=Somewhat Agree, A=Agree and SA=Strongly Agree.

\subsection{Research Question Two: How Do Training and Development Affect the Performance of Senior Administrative Staff in UEW?}

The second research question was answered with regression analysis and the results can be found in Table 5 . This type of regression is a standard multiple regression used to analyse the effect of training and development on the performance of senior administrative staff of University of Education, Winneba. Three main constructs that constituted training and development variable were T \& D needs Assessment, T \& D techniques and perception of $\mathrm{T} \& \mathrm{D}$. The dependent variable which was employee performance together with independent variables had scale items making them continuous variables. The regression results in Table 5 shows that all constructs of training and development significantly affected employee performance. The individual contribution and significance effect of constructs of training and development indicated with standardised beta and Sig respectively revealed that training and development techniques had the highest contribution and significance effect $(\mathrm{R}=.540, \mathrm{Sig}=.000)$ followed by training and development needs assessment $(\mathrm{R}=.164, \mathrm{Sig}=0.47)$ and perception of training and development $(\mathrm{R}=.153$, Sig. $=0.50)$ in explaining the variance in employees' performance. It is also instructive to indicate that the overall contribution of the constructs of training and development indicated by $\mathrm{R}$ - square was approximately $62 \%$ in explaining the variance of employee performance. The finding agrees with the findings of Sumaiya and Sahibzada (2017) who also found that training nd development methods/techniques significantly affected employee performance in private and public 
companies in Malaysia. This result suggests that there are other variables contributing to about $38 \%$ of the variance in employee performance that the regression model used by this study did not consider.

Table 5. Regression analysis on the effect of component of $\mathrm{t} \& \mathrm{~d}$ on performance

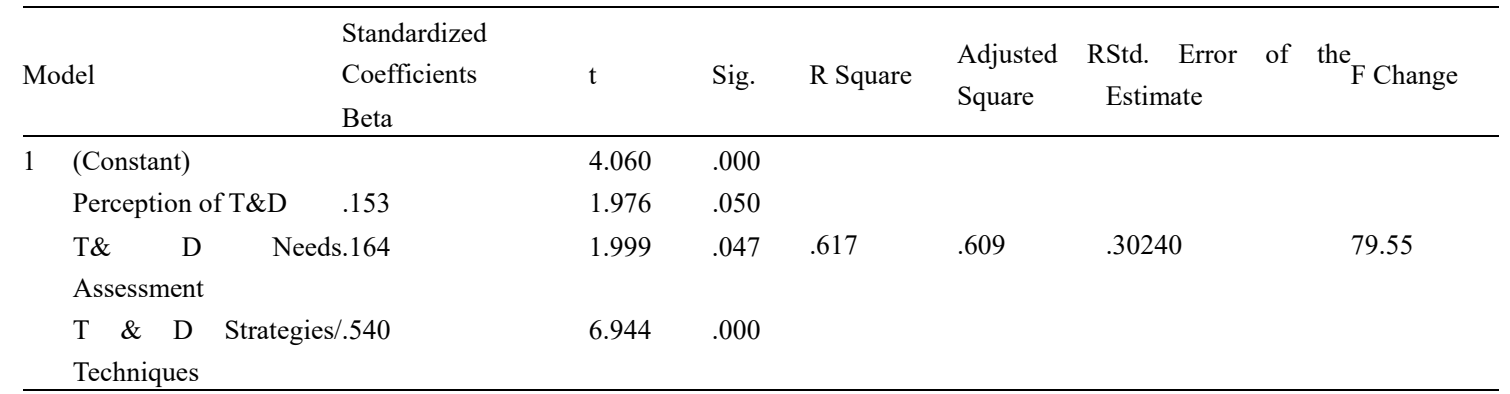

Dependent Variable: Employee Performance.

Source: Field survey (2018)

\subsection{Testing of Hypotheses of the Study}

The study hypothesised that:

\section{Hypothesis one}

$\mathrm{H}_{1}$ : There is a statistically positive and significant relationship between employees'performance and constructs of training and development.

The first hypothesis of the study was tested with the use of the Pearson correlation coefficient. This statistical tool was used to determine the relationship between (continuous) dependent and independent variables. The results of the Pearson correlation matrix can be seen in Table 6. The correlation matrix (Table 6) indicates that there was a strong positive significant but weak, positive and insignificant relationship respectively between $\mathrm{T} \&$ $\mathrm{D}$ techniques and employee performance $\left(\mathrm{r}=762^{* *}\right.$; Sig=.000; $\left.\mathrm{p} \leq 0.005\right)$; T\& D needs analysis $\left(\mathrm{r}=.665^{* *}\right.$, $\mathrm{Sig}=000, \mathrm{P} \leq 0.05)$ and perception of $\mathrm{T} \& \mathrm{D}(\mathrm{r}=639 * *, \mathrm{Sig}=000, \mathrm{P} \leq 0.05)$.

Table 6. Correlation matrix on relationship between employee performance and training \& development

\begin{tabular}{|c|c|c|c|c|c|}
\hline & & Perception of T \& D & $\begin{array}{l}\mathrm{T} \& \mathrm{D} \\
\text { Assessment }\end{array}$ & s & Performance \\
\hline \multirow[t]{3}{*}{ Perception of Training } & Pearson Correlation & 1 & $.719^{* *}$ & $.677^{* *}$ & $.639^{* *}$ \\
\hline & Sig. (2-tailed) & & .000 & .000 & .000 \\
\hline & $\mathrm{N}$ & 153 & 153 & 152 & 153 \\
\hline Training & andPearson Correlation & $.719^{* *}$ & 1 & $.721^{* *}$ & $.665^{* *}$ \\
\hline \multirow[t]{2}{*}{ Development Needs } & Sig. (2-tailed) & .000 & & .000 & .000 \\
\hline & $\mathrm{N}$ & 153 & 153 & 152 & 153 \\
\hline Training & andPearson Correlation & $.677^{* *}$ & $.721^{* *}$ & 1 & $.762^{* *}$ \\
\hline Development & Sig. (2-tailed) & .000 & .000 & & .000 \\
\hline Techniques & $\mathrm{N}$ & 152 & 152 & 152 & 152 \\
\hline \multirow[t]{3}{*}{ Employee Performance } & Pearson Correlation & $.639^{* *}$ & $.665^{* *}$ & $.762^{* *}$ & 1 \\
\hline & Sig. (2-tailed) & .000 & .000 & .000 & \\
\hline & $\mathrm{N}$ & 153 & 153 & 152 & 153 \\
\hline
\end{tabular}

**. Correlation is significant at the 0.01 level (2-tailed).

Source: Field survey (2017).

This means that any percentage increase in the components of training and development would result in the same percentage increment in employee performance (and the vice versa) among senior administrative staff of the university. The result also means that training and development has a very positive, strong and significant relationship with employees' performance. The results agree with that of Amadi (2014) who also found that training and development had positive and significant relationship with employee performance among workers of Safaricom in Nairobi, Kenya. Based on the significant relationship established between training and 
development and employee performance, the alternative hypothesis of the study was accepted that there is statistically positive and significant relationship between employee's performance and constructs of training and development.

\subsection{Hypothesis two}

$\mathrm{H}_{1}$ : There is statistically significant difference between sex and factors of the study such as $T \& D$ needs assessment, $T \& D$ Techniques and perception of $T \& D$ and employee performance.

Independent t-test statistics was used to analyse and test for hypothesis two of the study. A categorical variable such as sex (male and female) was used with continuous variables (perception of T \& D, T \&D needs assessment and T \& D techniques) constituting training and development factor of the study. The results can be seen in Table 7.All t- values reported for the variables were in line with the equal variance assumed because all the Sig. values obtained under the Levene's test for equality of variances were above .05 threshold. This means that none of the assumptions for using t-test was breached. The results as indicated by the Sig (2 tailed) under t-test for equality of means in Table 7 means that there were no statistically significance differences in scores respectively for male and female perception of $\mathrm{T} \& \mathrm{D}[(\mathrm{M}=3.08, \mathrm{SD}=.516 ; \quad(\mathrm{M}=2.99, \mathrm{SD}=.431) ; \mathrm{t}(152)=.297)]$; $\mathrm{T} \& \mathrm{D}$ needs assessment $[(\mathrm{M}=3.08, \mathrm{SD}=.450 ; \quad(\mathrm{M}=3.01, \mathrm{SD}=.379) ; \mathrm{t}(152)=.322)] ; \quad \mathrm{T} \& \mathrm{D}$ techniques $[(\mathrm{M}=2.84$, $\mathrm{SD}=.559 ; \quad(\mathrm{M}=2.77, \mathrm{SD}=.455) ; \mathrm{t}(152)=.392)] ;$ and employee performance $[(\mathrm{M}=3.29, \mathrm{SD}=.525 ; \quad(\mathrm{M}=3.18$, $\mathrm{SD}=.430) ; \mathrm{t}(152)=.297)]$.

Table 7. Differences in Perception of the Factors of the Study Based on Sex of Respondents

\begin{tabular}{ll}
\hline Group Statistics & $\begin{array}{l}\text { Levene's Test fort-test for Equality of Means } \\
\text { Equality of Variances }\end{array}$ \\
\hline
\end{tabular}

Sig. (2-tailed)

\begin{tabular}{|c|c|c|c|c|c|c|c|c|c|}
\hline & & & & & Std. Err & & & & \\
\hline & Sex & $\mathrm{N}$ & Mean & Std. Dev. & Mean & $\mathrm{F}$ & Sig. & $\mathrm{t}$ & \\
\hline Perception of T \& D & male & 80 & 3.08 & .516 & .05785 & 1.126 & .290 & 1.046 & .297 \\
\hline & female & 73 & 2.99 & .431 & .05044 & & & & \\
\hline$\&$ & Needsmale & 80 & 3.08 & .450 & .05034 & .168 & .682 & .993 & .322 \\
\hline Assessment & female & 73 & 3.01 & .379 & .04434 & & & & \\
\hline T \& D Techniques & male & 80 & 2.84 & .559 & .06244 & 1.323 & .252 & .859 & .392 \\
\hline & female & 72 & 2.77 & .455 & .05361 & & & & \\
\hline Performance & male & 80 & 3.29 & .525 & .05870 & 2.193 & .141 & 1.470 & .144 \\
\hline & female & 73 & 3.18 & .430 & .05038 & & & & \\
\hline
\end{tabular}

Source: Field survey (2017).

Meanwhile, female administrative staff of the university perceived all the components of training and development lower than their male counterparts. This finding, however, disagrees with that of Coffie1, Boateng and Coffie, (2018) who found statistically significant differences among employees based on their sex. Based on the non-significance of the training and development, employee performance and sex of respondents, the study therefore rejected the alternative hypothesis which states that there is statistically significant difference between sex and factors of the study such as T \& D needs assessment, T \& D Techniques and perception of T \& D and employee performance.

\subsection{Hypothesis Three}

$\mathrm{H}_{1}$ : There is a statistically significant difference between tenure or years of working experience and the factors of the study such as $T \& D$ needs assessment, $T \& D$ techniques and the perception of $T \& D$ and employee performance.

Hypothesis three was also tested with the use of a two-way between-group analysis of variance (ANOVA) to explore the impact of working experience herein termed as tenure on the employee performance and constructs of training and development as measured by the life orientation test (LOT). Subjects were divided into three 
main groups according to their number of years of working in the university (Group 1: 1-5 years; Group 2: 6- 9 years; Group 3: 10 years and above) and the results can be found in Table 9. Respondents perceived employee performance higher $(\mathrm{M}=3.2406, \mathrm{SD}=.48409)$ followed by perception of $\mathrm{T} \& \mathrm{D}(\mathrm{M}=3.039 ; \mathrm{SD}=.478)$ and $\mathrm{T} \& \mathrm{D}$ needs assessment $(M=3.05 ; \mathrm{SD}=.418)$. Senior administrative staff with one to five years working experience perceived all the four factors of the study higher followed by staff with 6 to 10 years working experience. This means that staff with lesser years of working experience perceived the factors of the study higher than those who have been with the university for more than ten years. Meanwhile, there was statistically significance differences between tenure and perception of $\mathrm{T} \& \mathrm{D}[\mathrm{F}(4.765)=.003)], \mathrm{T} \& \mathrm{D}$ Techniques $[\mathrm{F}(4.899))=.003)]$, and employee performance $[\mathrm{F}(=4.767)=.003)]$. The eta square calculated with the formula eta square $=$ sum of square between groups/ total sum of square was high for perception of T \& D $(0.06) \mathrm{T} \& \mathrm{D}$ techniques $(0.90)$ and employee performance (0.096).

Table 9. Differences in respondents' perception of factors of the study based on tenure

\begin{tabular}{|c|c|c|c|c|c|c|c|c|}
\hline & & $\mathrm{N}$ & Mean & Std. Deviation & Std. Error & $\mathrm{F}$ & Sig & Eta square \\
\hline \multicolumn{2}{|c|}{ Perception of T1-5 years } & 36 & 3.21 & .579 & .096 & 4.767 & .003 & 0.06 \\
\hline \multirow[t]{4}{*}{$\& D$} & 6-10 years & 35 & 3.09 & .525 & .089 & & & \\
\hline & $11-15$ years & 50 & 2.94 & .381 & .054 & & & \\
\hline & $16-20$ years & 32 & 2.93 & .381 & .067 & & & \\
\hline & Total & 153 & 3.04 & .478 & .039 & & & \\
\hline \multicolumn{2}{|c|}{$\mathrm{T} \& \mathrm{D}$ Needs $1-5$ years } & 36 & 3.18 & .406 & .068 & 1.825 & .145 & 0.04 \\
\hline \multirow[t]{4}{*}{ Assessment } & 6-10 years & 35 & 3.05 & .447 & .076 & & & \\
\hline & $11-15$ years & 50 & 2.97 & .377 & .053 & & & \\
\hline & $16-20$ years & 32 & 3.01 & .443 & .078 & & & \\
\hline & Total & 153 & 3.05 & .418 & .034 & & & \\
\hline $\mathrm{T} \&$ & D1-5 years & 35 & 3.07 & .606 & .102 & 4.899 & .003 & 0.09 \\
\hline \multirow[t]{4}{*}{ Techniques } & $6-10$ years & 35 & 2.81 & .431 & .073 & & & \\
\hline & $11-15$ years & 50 & 2.74 & .525 & .074 & & & \\
\hline & $16-20$ years & 32 & 2.64 & .343 & .061 & & & \\
\hline & Total & 152 & 2.81 & .512 & .042 & & & \\
\hline \multirow[t]{5}{*}{ Performance } & $1-5$ years & 36 & 3.48 & .572 & .095 & 4.767 & .003 & 0.096 \\
\hline & $6-10$ years & 35 & 3.22 & .435 & .074 & & & \\
\hline & $11-15$ years & 50 & 3.19 & .459 & .065 & & & \\
\hline & $16-20$ years & 32 & 3.07 & .370 & .066 & & & \\
\hline & Total & 153 & 3.24 & .484 & .039 & & & \\
\hline
\end{tabular}

Source: Field survey (2017).

The results suggest that the statistically significant differences between various categorisation of years of working experience could only be established for only three variables of the study with exception of $\mathrm{T} \& \mathrm{D}$ needs assessment. Based on this, the alternative hypothesis which state that there is statistically significant difference between tenure or years of working experience and factors of the study such as T \& D needs assessment, T \& D Techniques and perception of T \& D and employee performance, was rejected.

\section{Conclusion and Recommendations}

The purpose of the study was to examine the effect of training and development on the performance of senior administrative staff at the University of Education, Winneba. Components of training and development looked at were senior administrative staff's general perception of training and development, training and development need assessment, training and development techniques. Employee performance was used as the dependent variable of the study. The study found that though employees had the interest in attending training programmes, majority of the respondents were not able to confirm that training of senior administrative staff of the University leads to acquisition of innovative ideas. This according to respondents was due to the fact training and development programmes hardly linked to the university's Strategic Plan. Mode of selection of trainees for training and development programmes was perceived not to be fair and T \& D was hardly organised based on needs assessment. Training and development techniques use mostly were job rotation and study leave with pay. The study also found that there was general lack of support from supervisors, colleagues and from the department or institution for trainees to transfer skills and knowledge acquired through training unto their jobs. 
There was a statistically positive significant relationship between employee performance and all constructs of $\mathrm{T}$ $\&$ D. All constructs of training and development were found to have significantly affected and explained about $62 \%$ of the variance in employee performance. Training and development techniques were the highest contributing construct followed by training and development needs assessment and perception of training and development in explaining the variance in employees' performance. There was no statistically significant difference between sex of respondents and the factors of the study such as training and development, and employee performance. Apart from T \& D needs assessment, there was a statistically significant difference between tenure (working experience) and employee performance as well as two constructs of training and development such as T \& D needs techniques and perception of T \& D.

The above findings indicate a need for certain action to take place by the Division of Human Resource of the University of Education, Winneba. It is therefore recommended that the management of the division of human resource should:

1. Link training and development programmes for senior administrative staff to the institutions' strategic policy by using performance appraisal to identify training and development needs of trainees. This will ensure that the right training and development programmes are carried out for the right people to ensure better employee performance.

2. Provide the needed resources and encourage work colleagues and supervisors to create the enabling environment and provide the necessary support for trainees to be able to transfer skills acquired through training and development unto their jobs.

3. Adopt some other training and development techniques (other than job rotation and study leave with pay) like mentoring and coaching since these methods have more propensity in ensuring employee performance.

4. Pay attention to years of working experience of senior administrative staff in designing training and development programmes for staff. This will avoid participants partaking in $\mathrm{T} \& \mathrm{D}$ as a formality and ensure that the right training and development programmes are carried out for the right people to enhance employee's performance.

\section{References}

Aiyahya, M. S., Norsiah, B. M., \& Alharbi, M. A. (2013). Review of Theory of Human Resources Development Training (learning) Participation. Journal of West East Institute Business and Economics, 2(1), 47-58. Retrieved from https://westeastinstitute.com/journals/jweibe/

Amadi, E. J. (2014). The effect of training and development on employees' performance at Safaricom Limited call centre, Nairobi, Kenya. Master of Business Administration Dissertation, University of Nairobi. Retrieved from http://erepository.uonbi.ac.ke/bitstream/handle/11295/78203/Amandi_

Becker, H. S. (1996). Notes on the concepts of commitment. American Journal of Sociology, 66, 32-40. Retrieved from http://dx.doi.org/10.1086/222820

Boadu, F., Dwomo-Fokuo, E., Boakye, K. J., \& Kwaning, O. C. (2014). Training and development: A tool for employee performance in the District Assemblies in Ghana. International Journal of Education and Research, 2(5), 514. Retrieved from: https://www.ijern.com/journal/May-2014/42.pdf

Coffie1, B. R., Boateng, K. A., \&Coffie, F. (2018). Achieving organisational commitment through HRM practices: The Ghanaian banking sector experience. International Journal of Business and Management, 13(5), 171-184.

Creswell, W. C. (2014). Educational research: Planning, conducting and evaluating quantitative and qualitative research (4th ed.). Harlow: Pearson Education Limited. Retrieved from http://basu.nahad.ir/uploads/creswell.pdf

Dessler, G. (2008). Human resource management (11th ed.). Boston: Prentice Hall. Retrieved from https://www.academia.edu/36247651/Human_resource_management_13th_ed_by_dessler

Elnaga, A., \& Imran, A. (2013). The effect of training on employee performance. European Journal of Business and Management 5(4), $137 . \quad$ Retrieved from http://www.scirp.org/(S(i43dyn45teexjx455qlt3d2q))reference/ReferencesPapers.aspx?ReferenceID=16248 09

Fugar, F.D.K., Ashiboe-Mensah, N.A. \& Adinyira, E. (2013). Human capital theory: Implications for the Ghanaian construction industry development. Journal of Construction Project Management and Innovation, 
3(1), 464-479. Retrieved from http://hdl.handle.net/123456789/7278

Gamage, P., \& Imbulana, L. (2013). Training development and performance ofemployee: $\quad$ Evidence $\quad$ from Shrilanka telecom. International Journal of Marketing, Financial Services and Management Research, 2(9), 12-24. Retrieved from http://www.indianresearchjournals.com

Gunu, U., Oni, E., Tsado, E., \& Ajayi, O. (2013). Empirical study of training and development as a tool for organisational performance: Case study ofselected banks in Nigeria. Kuwait Chapter of Arabian Journal ofBusiness and Management Review, 2(10), 78-86. Rtrieved from https://www.arabianjbmr.com/pdfs/KD_VOL_2_10/13.pdf

Jehanzeb, K., \& Bashir, N. A. (2013). Training and development program and its benefits to employees and organisation: A conceptual study. European Journal of Business and Management 5(2), 243-244. Retrieved from https://www.researchgate.net/publication/274704136

Khan, M. T., Khan, N. A., \& Mahmood, K. (2012). An organisational concept of human resource development: How human resource management scholars view HRD. Universal Journal of Management and Social Sciences, 2(5). 36-47. Retrieved from http://www.aygrt.isrj.net

Kum, F. D., \& Cowden, R. (2014). The impact of training and development onemployee performance: A case study of Escon Consulting. Singaporean Journal of Business Economics, and Management Studies, 3(3), 1-21. Retrieved from: https://singaporeanjbem.com/pdfs/SG_VOL_3_(3)/7.pdf

Mansour, M. (2013). Evaluation of training in organisations: An empirical investigation from a developing country. International Journal of Education and Research, 1(6), 1-12. Retrieved from https://www.ijern.com/journal/June-2013/16.pdf

Mullins, L. J. (2010). Management \&organisationalbehaviour (9th ed.). Harlow, England: Pearson Education Limited.

Naris, N. S., \& Ukpere, I. W. (2009). The effectiveness of an HR code: Staff development and training at the Polytechnic of Namibia. African Journal of Business and Management, 3(12), 879-889. https://doi.org/10.5897/AJBM09.300

Noe, R. A. (2010). Employee training and development (5th ed.). New York: McGraw-Hill Irwin. Retrieved from http://dl.icdst.org/pdfs/files/03c0e71a553afb8c7c5f67b39234c87d.pdf

Ongori, H., \& Nzonzo, C. J. (2011). Training and development practices in an organisation: An intervention to enhance organisational effectiveness. International Journal of Engineering and Management Sciences, 2(4), 187-188. Retrieved from http://scienceandnature.org/IJEMS-Vol2(4)-Oct2011/IJEMS_V2(4)3.pdf

Sefenu, J. C., \& Nyan, J. (2017). Human resource management. Cape Coast, Ghana: University of Cape Coast Press.

Segbenya, P., \& Aggrey. (2018). Effect of work conflict on employees' job satisfaction: The case of College of Distance Education, University of Cape Coast. European Scientific Journal, 14(7), 313-323. https://doi.org/10.19044/esj.2018.v14n7p313

Sultana, A., Irum, S., Ahmed, K., \& Mehmood, N. (2012). Impact of training on employee performance: A study of Telecommunication Sector in Pakistan. Interdisciplinary Journal of Contemporary Research in Business, 4(6), 23-37. Retrieved from https://journal-archieves24.webs.com/646-661.pdf

Sumaiya, S., \& Sahibzada, M. H. (2017). The effect of training and development on employee performance in private company, Malaysia. International Journal of Education, Learning and Training, 2(2), 42-56. Retrieved from http://www.ftms.edu.my/journals/index.php/journals/ijelt

Werner, M. J., \& DeSimone, L. R. (2012). Human resource development (6th ed.). Australia: South-Western Cengage Learning. https://doi.org/10.1007/s11575-013-0197-9

\section{Copyrights}

Copyright for this article is retained by the author(s), with first publication rights granted to the journal.

This is an open-access article distributed under the terms and conditions of the Creative Commons Attribution license (http://creativecommons.org/licenses/by/4.0/). 